\title{
Physical activity and gene association with human obesity
}

\author{
Authors' Contribution: \\ A Study Design \\ B Data Collection \\ C Statistical Analysis \\ D Data Interpretation \\ E Manuscript Preparation \\ F Literature Search \\ G Funds Collection
}

\author{
Katarzyna Świtała ABDEF, Agata Leońska-Duniec ABDEF \\ Faculty of Physical Education, Gdansk University of Physical Education and Sport, \\ Gdansk, Poland
}

\section{abstract}

The obesity is a leading cause of health problems all over the world. It is a comlex health abnormality that is influenced by developmental, behavioural, environmental, and genetic factors. Although the role of physical activity and diet in regulation of body weight is well described, the genetic variants potentially influencing the characteristics and range of the body's adaptive response to physical activity in healthy individuals still remains mostly unknown. The main aim of this study is to review current evidence, through a literature review and the results of our studies, on the influence of selected molecular markers on the development of obesity, as well as the body composition changes in response to regular physical activity. We studied the most reliable candidate genes with a focus on catechol-O-methyltransferase gene (COMT), dopamine deceptor D2 gene (DRD2), fatty acid binding protein 2 gene (FABP2), fat mass and obesity-associated gene (FTO), and uncoupling protein 1 (UCP-1). This review provides information about recent genetic research progressions in adiposity, as well as molecular mechanisms, associated phenotypes, as well as their implications for human health, physical performance, and adaptive changes in response to physical activity.

Key words: sport genetics, obesity, physical activity, polymorphisms, adaptation.

\section{article details}

Article statistics: Word count: 3,927; Tables: 1; Figures: 0; References: 122

Received: November 2021; Accepted: December 2021; Published: December 2021

Full-text PDF: http://www.balticsportscience.com

Copyright @ Gdansk University of Physical Education and Sport, Poland

Indexation: Celdes, Clarivate Analytics Emerging Sources Citation Index (ESCI), CNKI Scholar (China National Knowledge Infrastructure), CNPIEC, DOAJ, EBSCO - Central \& Eastern European Academic Source, EBSCO - SPORTDiscus, EBSCO Discovery Service, Google Scholar, Index Copernicus, J-Gate, Naviga (Softweco, Primo Central (ExLibris), ProQuest - Family Health, ProQuest - Health \& Medical Complete, ProQuest - Illustrata: Health Sciences, ProQuest Nursing \& Allied Health Source, Summon (Serials Solutions/ProQuest, TDOne (TDNet), Ulrich's Periodicals Directory/ ulrichsweb, WorldCat (OCLC)

Funding: This research received no specific grant from any funding agency in the public, commercial, or not-for-profit sectors.

Conflict of interests: Corresponding author:

Open Access License: Authors have declared that no competing interest exists.

Ph.D. Student of Gdansk University of Physical Education and Sport, 80-336, Gdansk, Poland; e-mail: katarzyna. switala@awf.gda.pl

This is an open access article distributed under the terms of the Creative Commons Attribution-Non-Commercial-NoDerivatives 4.0 International (https://creativecommons.org/licenses/by-nc-nd/4.0/), which permits use, distribution, and reproduction in any medium, provided the original work is properly cited, the use is non-commercial and is otherwise in compliance with the license. 


\section{INTRODUCTION}

Human obesity and overweight have been considered as a worldwide epidemic [1]. These days excessive body weight gain is defined as a civilization disease and has become one of the largest public health problems [2], since nearly $40 \%$ of adults are overweight and $10-15 \%$ are obese all over the world [3].

The World Health Organisation (WHO) has defined obesity in adults as the body mass index (BMI) of $\geq 30 \mathrm{~kg} / \mathrm{m}^{2}$ and overweight as the BMI between 25 and $30 \mathrm{~kg} / \mathrm{m}^{2}$ [4]. According to scientists, the higher the BMI, the greater the risk of many medical problems. Its relationship with the occurrence of cardiovascular diseases (CVD), such as hypertension and coronary hearts diseases, as well as type 2 diabetes (T2D), lipid disorders, some types of cancer, and overall mortality has been confirmed [5, 6]. Moreover, a high BMI is also associated with infertility [7], which mainly concerns ovulatory disorders in the case of women $[8,9]$.

However, measurement of BMI has some limitations, since it takes into account only two parameters: a person's weight and height. This parameter cannot show the extent of adipose tissue (AT) in different individuals. The prevalence of percentage AT is different depending on gender, age, and ethnic origin. For instance, women have more subcutaneous adipose tissue (SAT), while men have fat, predominantly distributed to the visceral adipose tissue (VAT) around the abdominal organs creating abdominal obesity [10-12]. When it comes to the ethnic origin, Africans especially African women tend to be more obese and have a different body fat distribution than European woman [13, 14].

As mentioned, BMI does not measure AT directly; on the other hand, some studies have shown that BMI is partly correlated with more direct measures of body fat obtained from skinfold thickness measurements, bioelectrical impedance, underwater weighing, dual energy x-ray absorptiometry (DXA), and other methods [15-16].

Abdominal obesity is also known as visceral obesity, which refers to VAT. This parameter was recognised by the WHO in 1997 in order to perfect BMI. Waist circumference (WC) is a measure of abdominal obesity and is associated with all-cause mortality [17-18]. Furthermore, recent studies have shown that visceral obesity is increasing at an even higher rate than general obesity [19].

According to many studies, developmental, behavioural, environmental, and/or genetic factors have been considered an integral component of weight management and have an influence on future morbidity [20]. Physical activity (PA) is the most crucial factor in order to maintain appropriate body weight as per WHO statement. What is more, the benefits of PA are considered as effective prophylactic in regard to preventing CVD and many other medical problems [21]. Low PA among adults can lead to a higher prevalence of metabolic disorders such as heart disease, hypertension, T2D, and some cancers [22-23]. According to the recent studies, parental PA plays a positive role in modulation of the progeny's phenotype of their children. Interestingly, both the mothers' and fathers' PA - before their child is conceived - may be one of the appropriate way to potentially improve their progeny's health [24-25]. Current evidence demonstrates the protective effect of the parents' training/exercise on their progeny in relation to the general prevention of chronic diseases, including human obesity, T2D, and hypertension [26].

In addition, environmental and genetic factors are highly associated with human obesity. They play a key role in the regulation of body weight, since there are genes involved in control of energy consumption and expenditure, lipid and carbohydrates metabolism, adipogenesis, thermogenesis, as well as cell differentiation [27]. The heritability of BMI, which is defined as proportion of inter-individual variation attributable to genetic factors, has been estimated 
to be $40-70 \%$ [28]. In addition, more than 600 genes and chromosomal regions have been characterised to take part in body weight and energy metabolism regulation [27]. The most reliable molecular markers are presented in Table 1.

Table 1. Molecular markers associated with human obesity and effectiveness of exercise training programmes

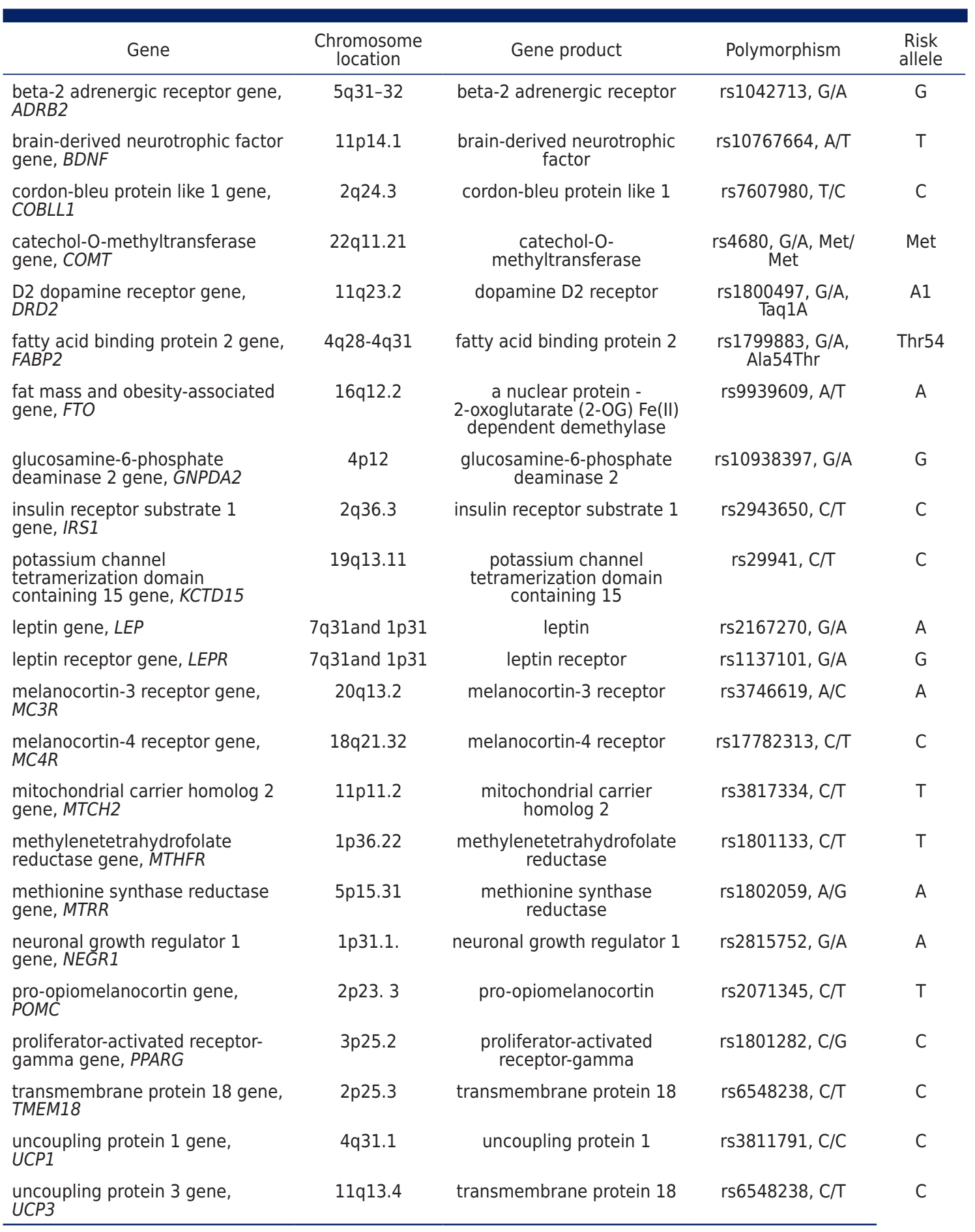

There are three types of human obesity correlated with genes. Monogenic obesity is described as rare and severe early-onset obesity with abnormal feeding behaviour and endocrine disorders. The influence of genetics is enormous and only little dependent on environmental factors. This form of obesity is mainly due to mutations in genes of the leptin/melanocortin axis involved in food intake regulation. Among the genes associated with the development of 
monogenic obesity, e.g. leptin $(L E P)$ and leptin receptor ( $L E P R)$, proopiomelanocortin $(P O M C)$, and proconvertase 1 (PC1) can be distinguished. This type of adiposity involves only $2-3 \%$ of obese children and adults [29].

Syndromic obesity is associated with mental retardation, dysmorphic features, and organspecific developmental abnormalities. This type of obesity is responsible for $2 \%$ of obesity in adults and children [30].

The last but not least type of adiposity related to genes is polygenic obesity. This kind of obesity includes about $95 \%$ cases and according to many studies is highly associated with environmental factors, such as low physical activity, excessive caloric intake, the intrauterine environment, medications, socioeconomic status, and possibly novel factors, such as insufficient sleep, endocrine disruptors, and the gastrointestinal microbiome [31]. Although the mentioned factors are quite well described in the development of obesity, the genetic background still remains mostly unknown. Additionally, only a few polymorphisms have been described in the context of their potential influence on the extent and the nature of the response to training in healthy and obesity individuals [32].

The main aim of this study is to review current evidence, through a literature review and the results of our studies, on the influence of gene variants on the development of obesity, as well as on characteristics and range of the body's adaptive response to training. We studied the most reliable candi $\neg$ date genetic markers with a focus on catechol-O-methyltransferase gene (COMT), dopamine receptor D2 gene (DRD2), fatty acid binding protein 2 gene (FABP2), fat mass and obesity-associated gene (FTO), and uncoupling protein 1 (UCP-1). This review provides information about recent genetic research progressions in adiposity, as well as molecular mechanisms, associated phenotypes, as well as their implications for human health, physical performance, and adaptive changes in response to physical activity.

\section{COMT}

The COMT gene is located on the long arm of chromosome 22 and encodes catecholO-methyltransferase, which is a major regulator of dopaminergic and adrenergic neurotransmission. The COMT enzyme transfers a methyl group from S-adenosyl-L-methionine (SAM) to one of the catecholic hydroxyls, which has a role in inactivation of catecholamine neurotransmitters and catechol hormones such as dopamine (DA) [33]. Two isoforms are distinguished: the soluble form (S-COMT) and the membrane-bound form (MB-COMT). The second one is expressed mostly in brain neurons and is engaged in the control of extracellular DA levels in the prefrontal cortex. It has been demonstrated to be involved in neuropsychiatric disorders and neurobiology of cognition, emotions, behaviour, sleep regulation, pain processing and perception, addictive behaviour, and neurodegeneration [33-35]. In result, the enzyme's activity may also play a crucial role in the development of sport abilities.

The main cause of variation in the enzyme's activity is a common single nucleotide polymorphism (SNP) within the coding region of the COMT gene involving a $\mathrm{G}$ to A transition, resulting in the substitution of valine for methionine (Val158Met; rs4680). The presence of the Met allele has been shown to reduce the activity of COMT, because of its higher thermolability, which in turn increases the DA levels [36].

In a study including 57 Asian elite athletes, Abe et al. [37] examined the interaction between the SNPs influencing DA system functions and swimmers' competitive performance. They noted an effect of the rs4680 polymorphism on a swimmer's competitive performance. The Met allele carriers demonstrated a higher mean value of FINA points and were more often elite athletes than the Val allele carriers. They proposed that swimmers with the Met allele 
might achieve outstanding sports results under high pressure due to their superior executive control. Another study performed on 75 participants undergoing 17 weeks of running training demonstrated that individuals with the Val/Val genotype demonstrated greater executive control abilities after aerobic exercise training than the Met allele carriers. It was assumed that an increase in physical fitness causes improved cognitive functioning via dopaminergic modulation [38]. Abe et al. [37] suggested that improving the athletic performance of Val/Val swimmers might be possible by applying an exhaustive training to improve aerobic capacity. However, the results obtained by Zmijewski et al. did not confirm significant differences in the genotype distributions or allele frequencies between in elite short- and long-distance swimmers, as well as sedentary controls [39].

In addition, the COMT Val158Met polymorphism was associated with baseline fat measures and seemed to alter the effect of the exercise intervention on fat loss in a group of 173 postmenopausal women. It was found that carriers of the Met/Met genotype had higher baseline fat levels and lost less fat after an exercise intervention (225 min/wk of moderateintensity exercise for one year) compared with carriers of the Val/Val genotype [40]. Witte et al. also show significant interactions of the COMT genotype and dietary intervention with regard to cognition. A better cognitive response to dietary interventions for the $\mathrm{Val} / \mathrm{Val}$ genotype carriers compared to carriers of one or two the Met-alleles was described [41].

\section{DRD2}

Dopamine (DA; 3,4-dihydroxy-phenylethylamine) is an essential catecholamine neurotransmitter that regulates multiple physiological and cognitive functions including the development of fatigue, which leads to a decrease in an intensity or interruption of exercise, through modulation circuits linked to the motor control and thermoregulatory, as well as motivation and reward systems [42-44]. The physiological roles of DA were first described in 1958 [34]. The first evidence of the association between DA and exercise dates from the 1970s and the 1980s in studies with rats which suggested that the DA signal system may be associated with physical activity-related behaviours [45-47]. DA activity mainly depends on DA receptors density and function [48]. There have been identified five DA receptors among humans: DRD1, DRD2, DRD3, DRD4, DRD5 [49], which are mostly present in the central nervous system specifically in the hippocampal dentate gyrus and subventricular zone. DA receptors are also expressed in the periphery, more prominently in kidneys and the vasculature [50-51].

The most likely candidate gene of DA system associated with individual differences in cognitive abilities which may underlie differences in achieving remarkable results in professional sports competition and everyday physical activity is the $D R D 2$ gene. It is located on chromosome 11, contains 8 exons and 6 introns, and spans 65,56 kb [52]. The DRD2 gene is probably regulated by ankyrin repeat and kinase domain containing 1 gene (ANKK1) through Nuclear FactorkappaB (NF-kB). Genetic variations in $D R D 2$ can alter dopamine signalling and modify the rewarding effects of food; moreover, some studies investigated the association of the DRD2 polymorphisms with BMI and hedonic hunger [53], since dopamine plays an important role in the regulation of appetite and the growth hormone [54-55]. Furthermore, variations in the FTO gene are the strongest polygenic determinants of obesity [56], and inactivation of this gene impairs DRD2-dependent neurotransmission and function in rodents [57].

SNP located in $D R D 2$, the insertion (Ins) or the deletion (Del) of cytosine (C) in the promoter region of the gene at position -141 (-141C Ins/Del; rs1799732) [58] has been linked to BMI and hedonic hunger. The -141C Del allele produces lower expression of DRD2. The -141C Ins/Del allele has been related with reduced promoter activity which effects the decreased protein expression [59]. Aliasghari et al. found significant differences in the allele frequencies of this polymorphism between the overweight/obese and normal weight controls. The frequency of Del (rs1799732) allele was higher in overweight/obese individuals [60]. 
The Taq1A polymorphism (G/A, rs1800497) has been most frequently studied polymorphism of $D R D 2$. The A1 allele of this polymorphism has been associated with reduced $D R D 2$ density in the striatum, decreased reward sensitivity, and reduction in novelty-seeking behaviour. For instance, Wang et al. found that those with lower D2 receptor densities in the striatum were more likely to be obese [61]. Pohjalainen et al. indicated that individuals who possess A1 allele of $D R D 2$ are more often addicted to exercise since possession of A1 allele is significantly associated with lower $D R D 2$ expression [62]. What is more, this study has shown possession of the A1 allele of $D R D 2$ may play a significant role in the process of PA addiction among male participants, hence exercise addiction may play a key role in preventing having of other addictive behaviours (e.g. binge eating disorder, BED) among male participants who possess the A1 allele of DRD2 [63].

Cameron et al. also established that the TaqIA genotype was associated with body weight loss, fat mass loss, and a decrease in BMI post-intervention in a group of obese postmenopausal women. Specifically, carriers of the A1 allele exhibited smaller reductions in body weight, fat mass, and BMI pre- and post-intervention in a group of women who entered a combined 6-month resistance training program and caloric restriction intervention, whereas no interactive effects were found in a group of women only limiting calories [64].

\section{FABP2}

One of the most promising candidate genetic markers is FABP2 [65]. The gene is located in the long arm of chromosome 4 and encoded an intracellular protein which is a member of the FABPs superfamily [66]. The intestinal FABP2 binds saturated and unsaturated longchain fatty acids and is involved in the synthesis of triglyceride-rich lipoproteins. In addition, the gene product takes part in the absorption, intracellular transport, and metabolism of dietary fatty acids and their acyl-CoA esters in small intestine [67-69]. Thus, the FABP2 is an extensively studied candidate gene related to metabolic disorders including obesity, diabetes, and metabolic syndrome [67-68,70-72].

In 1995, a nucleotide transition from G to A at codon 54 in exon 2 of the FABP2 gene that results in an alanine (Ala) to a threonine (Thr) change (Ala54Thr; rs1799883) was described [67]. Many studies have shown that this missense variation is strongly associated with lipid and carbohydrates metabolism [67-68]. The carriers of the Thr54 variant of FABP2 have nearly twice the affinity for long-chain fatty acids than those with the Ala54 allele. This evidence supports the potential role of the FABP2 Ala54Thr polymorphism in the aetiology of human overweight and obesity $[67,73]$. Recently, a sexual dimorphism regarding BMI was described for the polymorphism [70, 73].

Although the association between the Ala54Th SNP and excess body mass is well confirmed, the gene $\times$ physical activity interaction and its connection with the athlete status is not clear. Nasibulina et al. suggested that while the excess absorption of long-chain fatty acids during sedentary state is considered as a risk factor for overweight and obesity, among athletes this condition can give additional benefit for endurance performance [74]. Indeed, they revealed that the Thr54 allele frequency was higher in elite Russian endurance and combat athletes compared to controls (32.2\%). A previous study also showed that higher availability of free fatty acids can provide for enhanced oxidative potential as evidenced by an increase in $\mathrm{VO}_{2} \max$ and a decreased running time in trained runners [75].

Our earlier findings confirm that the carriers of the Thr54 allele had higher BMI compared with the Ala54 carriers, suggesting that the Thr54 variant is a risk allele engaged in excess body mass in Polish women. On the other hand, we did not found evidence of a relationship between the FABP2 Ala54Thr polymorphism and physical activity on the selected body mass 
measurements as well as with biochemical parameters [76]. These results are consistent with Han [81], who showed that a 12-week regular aerobic training can beneficially prevent obesity-related traits; however, none of the examined parameters significantly changed across the FABP2 genotypes [81]. Furthermore, total cholesterol, high-density lipoprotein (HDL), and triglycerides (TGL) levels were not significantly changed by the joint effects of the genotypes and cardiorespiratory fitness in 837 participants from Japan [77].

\section{FTO}

In 2007, three different research groups have revealed that a group of polymorphisms in the first intron of FTO is related to body mass and body composition parameters, such as BMI, hip circumference, total body weight, body fat percentage, and cardiometabolic traits [78-80]. As a result, it has been associated with overweight and obesity risk among numerous ethnic populations as well as various age groups [81-84].

The human FTO gene is localized to long arm of chromosome 16 and encodes a 2-oxoglutarate (2-OG) Fe (II) dependent demethylase [78, 89]. FTO is a nuclear protein which is able to remove methyl groups from 3-methylthymine in single-stranded DNA, as well as 3-methyluracil and 6-methyladenosine in single-stranded RNA nucleotides [85]. Thus, the gene product is involved in regulation of genes transcription and posttranslational modifications, as well as repair and/ or modification of nucleic acid by demethylation $[82,85]$. It was suggested that this nuclear protein can regulate the pathways controlling e.g. food intake, nutrient preference, appetite and satiety, as well as control over eating [82].

A/T polymorphism (rs9939609), which is most often described in the context of obesity-related traits, is located in the first intron of the FTO gene. It was suggested to play an important role in the regulation of transcription, either to up- or down-regulate the FTO expression [80]. The A allele was characterized as a risk allele, because it is related to $20 \%-30 \%$ higher risk of overweight and obesity. Frayling and colleagues showed that $\sim 16 \%$ of the examined populations are the AA homozygous, and these persons weigh $\sim 3 \mathrm{~kg}$ more when compared with the TT homozygous [78].

So far, only a few studies have tried to clarify the association between the FTO A/T polymorphism and sport predispositions or training-induced changes in athletes and sedentary individuals. In the study comparing 1089 participants, Heffernan et al. [86] suggested that the T allele is associated with increased body lean mass, muscle-related phenotypes, as well as elite athletic status. These results were confirmed by Guilherme et al. [87] who established that the FTO AA genotype is less frequent in Brazilian $(n=677)$ and Russian $(n=920)$ athletes more reliant on a lean phenotype and linked to a reduced proportion of slow-twitch muscle fibres, while it is over-represented in power and combat sport athletes of heavier weight categories. Additionally, a lower frequency of the AA and the AT genotype, as well as the A allele among elite Polish swimmers, was shown implying that some people may benefit from carrying the T allele. The TT homozygous person had 1.5-2.0 times higher chance of being an elite swimmer [86]. However, Eynon et al. [89] did not demonstrate a connection between the $\mathrm{A} / \mathrm{T}$ polymorphism and the elite athlete status in the group of Spanish $(\mathrm{n}=81)$, Polish $(\mathrm{n}=214)$, and Russian $(\mathrm{n}=256)$ athletes.

A large-scale meta-analysis revealed that the FTO effect on the risk of excess of body mass is $\sim 30 \%$ lower in physically active persons than in people leading a sedentary lifestyle [90]. These observations were confirmed by Li et al. who showed that living a physically active lifestyle is linked to a $40 \%$ reduction in the genetic predisposition to overweight and obesity [91]. In other studies, the effect size of the FTO polymorphisms was as much as $80 \%$ lower in physically active people [92-93]. However, not all studies have demonstrated the gene $\times$ 
physical activity interaction [94-95]. Although a study conducted on 201 healthy Caucasian women confirmed an association between the AA and AT genotypes and higher BMI, the gene $\times$ physical activity interaction was not shown [95].

\section{UCP 1}

The human UCP-1 gene is located on a long arm of chromosome 4, spans $13 \mathrm{~kb}$ and contains a transcribed region that covers $9 \mathrm{~kb}$ [96-97]. The gene product is located in the inner mitochondrial membrane mainly in brown adipose tissue (BAT), in which UCP1 allows protons to re-enter the matrix, bypassing the adenosine triphosphate (ATP) synthase [98]. UCP1 expression is highly induced when thermogenesis is required [99]. It was recently shown that mRNA and/or protein were detected not only in BAT but also in the white adipose tissue (WAT) [100-101], skeletal muscle [102], and longitudinal smooth muscle layers [103]. UCP1 plays a significant role in thermogenesis and energy expenditure; therefore, it has an influence on the pathogenesis of obesity and metabolic disorders in human [104-107].

Oppert et al. revealed that frequent A/G substitution at position -3826 upstream of the UCP1 gene (A-3826G, rs1800592) was associated with human obesity and weight gain in 261 Canadians. This was the first study to find a dependence between higher BMI and the G variant of UCP-1 in Canadians [108]. Until now, many association studies were conducted in various populations to explain the association of the A-3826G polymorphism with obesity phenotypes, T2D, and lipid/lipoprotein-related disease [108, 109-110].

Although, Kieć-Wilk et al. implied that UCP1 does not play a major role in the development of obesity and/or disturbances of glucose metabolism, in a study including 118 overweight and obese patients from Poland, they revealed increased levels of triglyceride (TG) and free fatty acids (FFA) and decreased levels of high-density lipoprotein (HDL) observed in carriers of the $\mathrm{G}$ allele. It was suggested that FFA-induced impairment of the HDL turnover and disturbance of the $\beta$-cell function, which are important risk factors for endothelial injury [111]. In addition, in a study including 113 Japanese obese participants who were treated with a combined low-calorie diet and exercise for 3 months, Kogure et al. showed that a decrease in the body weight was lower in the $\mathrm{G}$ allele carriers than in the A allele carriers, whereas the food intake, exercise, and initial BMI were similar in both groups [112]. These results confirmed previous data which indicated that the genetic variant of UCP1 is associated with resistance to lowcalorie diet, suggesting a role of UCP1 and BAT in the body weight regulation in humans [113].

\section{CONCLUSIONS}

Regular PA plays a key role in maintaining not only appropriate body weight but also body composition such as adipose and muscle tissue [114]. There are many reasons why greater PA is required to maintain an appropriate body weight. First of all, the current food environment encourages excess caloric intake and positive energy balance. Interestingly, the lifestyle during non-leisure PA has become increasingly sedentary, a trend that will continue [115]. Systematic PA is also associated with many health-related benefits, including a reduced risk of developing several chronic diseases such as CAD, T2D, metabolic syndrome (MS), and cancer. Even light-intensity PA may be associated with blood glucose reductions, whereas sedentary time may be unfavourably associated with its increased levels [116]. Additionally, genetic factors play a fundamental role in the regulation of body weight and body composition, since there are genes involved in regulation of energy expenditure, carbohydrates and lipid metabolism, appetite, thermogenesis, adipogenesis, as well as cell apoptosis and differentiation [32].

A genome-wide association studies (GWASs) have identified many SNPs in FTO and other genes such as, COMT, DRD2, FABP2, FTO, LEP , LEPR, MC4R, POMC, UCP1 [117-119] that 
are associated with the risk of developing obesity. Among these genes, FTO has been reported as the gene with the strongest correlation with adiposity [120-121]. However, the majority of identified gene variants have unknown biological functions and some of these studies yielded contradictory results, suggesting a need for further research into the functions of identified polymorphisms referred to adiposity. Additionally, only few SNPs have been described in the context of their potential effect on the extent and nature of the response to training program in healthy individuals from different populations [32, 91, 122]. Therefore, more replication studies are required in order to establish the role of the gene variants in the characteristics and range of the body's adaptive response to training and, consequently, to reducing the risk of obesity in the next generation. Understanding the genetics of biochemical and physiological processes would have a wide impact on individualization of training programs to be more effective and safer, improved recovery, medical care, traumatology, nutrition, supplementation, and many other fields.

\section{REFERENCES}

[1] Loret de Mola JR. Obesity and its relationship to infertility in men and women. Obstet Gynecol Clin North Am. 2009;36:333-346. https://doi.org/10.1016/j.ogc.2009.03.002

[2] Talmor A, Dunphy B. Female obesity and infertility. Best Pract Res Clin Obstet Gynaecol. 2015;29:498-506. https:// doi.org/10.1016/j.bpobgyn.2014.10.014

[3] NCD Risk Factor Collaboration (NCD-RisC). Trends in adult body-mass index in 200 countries from 1975 to 2014 : A pooled analysis of 1698 population-based measurement studies with $19 \cdot 2$ million participants. Lancet. 2016; 387: 1377-96. https://doi.org/10.1016/S0140-6736(16)30054-X

[4] HaidarYM, Cosman BC. Obesity epidemiology. Clin Colon Rectal Surg. 2011;24:205-210. https://doi.org/10.1055/s-0031-1295684

[5] Grundy SM, Cleeman JI, Daniels SR, et al. Diagnosis and management of the metabolic syndrome. An American Heart Association/National Heart, Lung, and Blood Institute Scientific Statement. Executive summary. Circulation. Cardiol Rev. 2005;13(6):322-327. https://doi.org/10.1161/CIRCULATIONAHA.105.169404

[6] Freedman DS, Horlick M, Berenson GS. A comparison of the Slaughter skinfold-thickness equations and BMI in predicting body fatness and cardiovascular disease risk factor levels in children. Am J Clin. Nutr. 2013;98(6):141724. https://doi.org/10.3945/ajcn.113.065961

[7] Hensrud DD, Klein S. Extreme Obesity: A New Medical Crisis in the United States. Mayo Clinic Proceedings. 2006;81:s5-10. https://doi.org/10.1016/S0025-6196(11)61175-0

[8] Castillo-Martinez L, Lopez-Alvarenga JC, Villa AR, Gonzalez-Barranco J. Menstrual cycle length disorders in 18-to 40-y-old obese women. Nutrition. 2003;19:317-320. https://doi.org/10.1016/S0899-9007(02)00998-X

[9] Koning AMH, Kuchenbecker WKH, Groen H, Hoek A, Land JA, Khan KS, Mol BWJ. Economic consequences of overweight and obesity in infertility: a framework for evaluating the costs and outcomes of fertility care. Hum Reprod Update. 2010;16:246-254. https://doi.org/10.1093/humupd/dmp053

[10] Fried SK, Lee MJ, Karastergiou K. Shaping fat distribution: new insights into the molecular determinants of depotand sexdependent adipose biology. Obesity (Silver Spring). 2015;23(7): 1345-52. https://doi.org/10.1002/oby.21133

[11] Schwartz RS, Shuman WP, Larson V, et al. The effect of intensive endurance exercise training on body fat distribution in young and older men. Metabolism. 1991;40(5):545-51. https://doi.org/10.1016/0026-0495(91)90239-S

[12] Link JC, Hasin-Brumshtein Y, Cantor RM, et al. Diet, gonadal sex, and sex chromosome complement influence white adipose tissue miRNA expression. BMC Genomics. 2017;18(1):89. https://doi.org/10.1186/s12864-017-3484-1

[13] Kuczmarski RJ, Flegal KM, Campbell SM, Johnson CL. Increasing prevalence of overweight among US adults. JAMA. 1994;272:205-11. https://doi.org/10.1001/jama.272.3.205

[14] Conway JM, Yanovski SZ, Avila NA, Hubbard VS. Visceral adipose tissue differences in black and white women. Am J Clin Nutr. 1995;61:765-71. https://doi.org/10.1093/ajcn/61.4.765

[15] Garrow JS, Webster J. Quetelet's index (W/H2) as a measure of fatness. Int J Obes. 1985;9(2):147-153.

[16] Wohlfahrt-Veje C, Tinggaard J, Winther K, et al. Body fat throughout childhood in 2647 healthy Danish children: Agreement of BMI, waist circumference, skinfolds with dual X-ray absorptiometry. Eur J Clin Nutr. 2014;68(6):66470. https://doi.org/10.1038/ejcn.2013.282

[17] Bigaard J, Frederiksen K, Tjonneland A, et al. Waist circumference and body composition in relation to all-cause mortality in middle-aged men and women. Int J Obes. 2005;29:778-784. https://doi.org/10.1038/sj.ijo.0802976

[18] Pischon T, Boeing H, Hoffmann K, et al. General and abdominal adiposity and risk of death in Europe. N Engl J Med. 2008;359:2105-2120. https://doi.org/10.1056/NEJMoa0801891

[19] Walls HL, Stevenson CE, Mannan HR, et al. Comparing trends in BMI and waist circumference. Obesity (Silver Spring). 2011;19(1):216-219. https://doi.org/10.1038/oby.2010.149

[20] Leskinen T, Kujala UM. Health-related findings among twin pairs discordant for leisure-time physical activity for 32 years: The twin active study synopsis. Twin Res Hum Genet. 2015;18(3):266-272. https://doi.org/10.1017/thg.2015.23

[21] Orkaby AR, Forman DE. Physical activity and CVD in older adults: an expert's perspective. Expert Rev Cardiovasc Ther. 2018;16(1):1-10. https://doi.org/10.1080/14779072.2018.1419062

[22] Wilson PWF, D'Augostino RB, Sullivan L, Parise H, Kannel WB. Overweight and obesity as determinants of cardiovascular risk. The Framingham experience. Arch Intern Med. 2002;162:1867-1872. https://doi.org/10.1001/ archinte.162.16.1867 
[23] Prospective Studies Collaboration. Body-mass index and cause-specific mortality in 900.000 adults: A collaborative analyses of 57 prospective studies. Lancet. 2009;373:1083-1096. https://doi.org/10.1016/S0140-6736(09)60318-4

[24] Vieira de Sousa Neto I, Fontes W, Prestes J, de Cassia Marqueti R. Impact of paternal exercise on physiological systems in the offspring. Acta Physiol (Oxf). 2021 Apr;231(4):e13620. https://doi.org/10.1111/apha.13620

[25] Davenport MH, Meah VL, Ruchat SM, et al. Impact of prenatal exercise on neonatal and childhood outcomes: A systematic review and meta-analysis. Br J Sports Med. 2018;52:1386-1396. https://doi.org/10.1136/ bjsports-2018-099836

[26] Harris JE, Baer LA, Stanford KI. Maternal exercise improves the metabolic health of adult offspring. Trends Endocrinol Metab. 2018;29(3):164-177. https://doi.org/10.1016/j.tem.2018.01.003

[27] Deram S, Villares SM. Genetic variants influencing effectiveness of weight loss strategies. Arq Bras Endocrinol Metabol. 2009;53(2):129-138. https://doi.org/10.1590/S0004-27302009000200003

[28] Maes HH, Neale MC, Eaves LJ. Genetic and environmental factors in relative body weight and human adiposity Behav Genet. 1997;27(4):325-351. https://doi.org/10.1023/A:1025635913927

[29] D’Angelo CS, Kohl I, Varela MC, et al. Obesity with associated developmental delay and/or learning disability in patients exhibiting additional features: report of novel pathogenic copy number variants. Am J Med Genet A. 2013;161(3):479-486. https://doi.org/10.1002/ajmg.a.35761

[30] Beales PL, Elcioglu N, Woolf AS, Parker D, Flinter FA. New criteria for improved diagnosis of Bardet-Biedl syndrome: Results of a population survey. J Med Genet A. 1999;36(6):437-446.

[31] Maes HH, Neale MC, Eaves LJ. Genetic and environmental factors in relative body weight and human adiposity. Behav Genet. 1997;27(4):325-351. https://doi.org/10.1023/A:1025635913927

[32] Leońska-Duniec A, Ahmetov II, Zmijewski P. Genetic variants influencing effectiveness of exercise training programmes in obesity - an overview of human studies. Biol Sport. 2016;33(3):207-214. https://doi.org/10.5604/20831862.1201052

[33] Bastos P, Gomes T, Ribeiro L. Catechol-o-methyltransferase (COMT): An update on its role in cancer, neurological and cardiovascular diseases. In: Reviews of Physiology, Biochemistryand Pharmacology, vol. 173. Springer Verlag; 2017, 1-39. https://doi.org/10.1007/112 20172

[34] Axelrod J, Tomchick R. Enzymatic O-Methylation of Epinephrine and Other Catechols. J Biol Chem. 1958, 233(3),702705. https://doi.org/10.1016/S0021-9258(18)64731-3

[35] Machoy-Mokrzyńska A, Starzyńska-Sadura Z, Dziedziejko V, et al. Association of COMT gene variability with pain intensity in patients after total hip replacement. Scand J Clin Lab Invest. 2019;79(3):202-207. https://doi.org/10.1 080/00365513.2019.1576920

[36] Qayyum A, Zai C, Hirata Y, et al. The role of the catechol-o-methyltransferase (COMT) geneVal158Met in aggressive behavior, a review of genetic studies. Curr Neuropharmacol. 2015;13(6):802-814. https://doi. org/10.2174/1570159X13666150612225836

[37] Abe D, Doi H, Asai T, et al. Association between COMT Val158Met polymorphism and competition results of competitive swimmers. J Sports Sci. 2018;36(4):393-397. https://doi.org/10.1080/02640414.2017.1309058

[38] Stroth S, Reinhardt RK, Thöne J, et al. Impact of aerobic exercise training on cognitive functions and affect associated to the comt polymorphism in young adults. Neurobiol Learn Mem. 2010;94(3):364-372. https://doi.org/10.1016/j. nlm.2010.08.003

[39] Zmijewski P, Leońska-Duniec A, Stuła A, Sawczuk M. Evaluation of the association of COMT Rs4680 polymorphism with swimmers' competitive performance. Genes. 2021;12:1641. https://doi.org/10.3390/genes12101641

[40] Tworoger SS, Chubak J, Aiello EJ, et al. The effect of CYP19 and COMT polymorphisms on exercise-induced fat loss in postmenopausal women. Obes Res. 2004;12(6):972-981. https://doi.org/10.1038/oby.2004.119

[41] Witte AV, Jansen S, Schirmacher A, Young P, Flöel A. COMT Val158Met polymorphism modulates cognitive effects of dietary intervention. Front Aging Neurosci. 2010;5;2:146. https://doi.org/10.3389/fnagi.2010.00146

[42] Cordeiro LMS, Rabelo PCR, Moraes MM, et al. Physical exercise-induced fatigue: The role of serotonergic and dopaminergic systems. Braz J Med Biol Res. Associacao Brasileira de Divulgacao Cientifica. 2017;19:50(12):e6432. https://doi.org/10.1590/1414-431x20176432

[43] Heyes MP, Garnett ES, Coates G. Central dopaminergic activity influences rats ability to exercise. Life Sci. 1985;36(7):671-677. https://doi.org/10.1016/0024-3205(85)90172-9

[44] Gerald MC. Effects of (+)-amphetamine on the treadmill endurance performance of rats. Neuropharmacol. 1978;17(9):703-704. https://doi.org/10.1016/0028-3908(78)90083-7

[45] Kelly MA, Rubinstein M, Phillips TJ, et al. Locomotor activity in D2 dopamine receptor-deficient mice is determined by gene dosage, genetic background, and developmental adaptations. J Neurosci. 1998;18(9):3470-3479. https:// doi.org/10.1523/JNEUROSCI.18-09-03470.1998

[46] Klinker F, Hasan K, Paulus W, Nitsche MA, Liebetanz D. Pharmacological blockade and genetic absence of the dopamine D2 receptor specifically modulate voluntary locomotor activity in mice. Behav Brain Mes. 2013;242:117-124. https:// doi.org/10.1016/j.bbr.2012.12.038

[47] Zhang M, Creese I. Antisense oligodeoxynucleotide reduces brain dopamine D2 receptors: Behavioral correlates. Neurosci Lett. 1993;161:223-226. https://doi.org/10.1016/0304-3940(93)90299-Z

[48] Wise RA. Role of brain dopamine in food reward and reinforcement. Philos Trans R Soc Lond B Biol Sci. 2006;361(1471):1149-1158. https://doi.org/10.1098/rstb.2006.1854

[49] Historical overview: Introduction to the dopamine receptors. In: The Dopamine Receptors. Springer; 2009, 1-22.

[50] Mishra A, Singh S, Shukla S. Physiological and functional basis of dopamine receptors and their role in neurogenesis: possible implication for Parkinson's disease. J Exp Neurosci. 2018;12:1179069518779829. https:// doi.org/10.1177/1179069518779829

[51] Kelly MA, Rubinstein M, Phillips TJ, et al. Locomotor activity in D2 dopamine receptor-deficient mice is determined by gene dosage, genetic background, and developmental adaptations. J Neurosci. 1998;18(9):3470-3479. https:// doi.org/10.1523/JNEUROSCI.18-09-03470.1998

[52] Grandy DK, Marchionni MA, Makam H, et al. Cloning of the cDNA and gene for a human D2 dopamine receptor. Proc Natl Acad Sci U S A. 1989;86(24):9762-9766. https://doi.org/10.1073/pnas.86.24.9762 
[53] Feistauer V, Vitolo MR, Campagnolo PD, Mattevi VS, Almeida. Evaluation of association of DRD2 TaqIA and-141C InsDel polymorphisms with food intake and anthropometric data in children at the first stages of development. Genet Mol Biol. 2018;41(3):562- 569. https://doi.org/10.1590/1678-4685-gmb-2017-0202

[54] Smith GP, Schneider LH. Relationship between mesolimbic dopamine function and eating behaviour. Ann NY Acad Sci. 1988;537:254-261. https://doi.org/10.1111/j.1749-6632.1988.tb42111.x

[55] Volkow ND, Wang GJ, Baler RD. Reward, dopamine and the control of food intake: implications for obesity. Trends Cogn Sci. 2011;15(1):37-46. https://doi.org/10.1016/j.tics.2010.11.001

[56] Frayling TM, Timpson NJ, Weedon MN, et al. A common variant in the FTO gene is associated with body mass index and predisposes to childhood and adult obesity. Science. 2007;316:889-894. https://doi.org/10.1126/science.1141634

[57] Hess ME, Hess S, Meyer KD, et al. The fat mass and obesity associated gene (FTO) regulates activity of the dopaminergic midbrain circuitry. Nat Neurosci. 2013;16:1042-1048. https://doi.org/10.1038/nn.3449

[58] Cordeiro Q, Siqueira-RobertoJ, Zung S, Vallada H. Association between the DRD2-141C insertion/deletion polymorphism and schizophrenia. Arq Neuropsiquiatr. 2009;67(2A):191-194. https://doi.org/10.1590/S0004-282X2009000200004

[59] Benton D, Young HA. A meta-analysis of the relationship between brain dopamine receptors and obesity: A matter of changes in behavior rather than food addiction? Int J Obes. 2016;40(1):12-21. https://doi.org/10.1038/ijo.2016.9

[60] Aliasghari F, Nazm SA, Yasari S, Mehdavi R, Bonyadi M. Associations of the ANKK1 and DRD2 gene polymorphisms with overweight, obesity and hedonic hunger among women from the Northwest of Iran. Eating and Weight Disorders - Studies on Anorexia, Bulimia and Obesity. 2021;26:305-312. https://doi.org/10.1007/s40519-020-00851-5

[61] Wang GJ, Volkov ND, Logan J, et al. Evidence of brain dopamine pathology in obesity. Lancet. 2001; 357(9253):354357. https://doi.org/10.1016/S0140-6736(00)03643-6

[62] Pohjalainen T, Rinne JO, Någren K, et al. The A1 allele of the human D2 dopamine receptor gene predicts low D2 receptor availability in healthy volunteers. Mol Psychiatry. 1998;3(3):256-260. https://doi.org/10.1038/sj.mp.4000350

[63] Lee CG, Moon H, Park S. The effects of dopamine receptor genes on the trajectories of sport participation from adolescence through young adulthood. Ann Hum Biol. 2020;47(3):256-262. https://doi.org/10.1080/03014460.202 0.1736629

[64] Cameron JD, Riou ME, Tesson F, et al. The TaqIA RFLP is associated with attenuated intervention-induced body weight loss and increased carbohydrate intake in post-menopausal obese women. Appetite. 2013;60(1):111-116. https://doi.org/10.1016/j.appet.2012.09.010

[65] Hertzel AV, Bernlohr DA. The mammalian fatty acid-binding protein multigene family: Molecular and genetic insights into function. Trends Endocrinol Metab. 2000;11(5):175-180. https://doi.org/10.1016/S1043-2760(00)00257-5

[66] Sweetser DA, Birkenmeier EH, Klisak IJ, et al. The Human and rodent intestinal fatty acid binding protein genes. A comparative analysis of their structure, expression, and linkage relationships. J Biol Chem. 1987;262(33): 1606016071. https://doi.org/10.1016/S0021-9258(18)47696-X

[67] Baier LJ, Sacchettini JC, Knowler WC, et al. An amino acid substitution in the human intestinal fatty acid binding protein is associated with increased fatty acid binding, increased fat oxidation, and insulin resistance. J Clin Invest. 1995;95(3):1281-1287. https://doi.org/10.1172/JCI117778

[68] Lowe JB, Sacchettini JC, Laposata M, McQuillan JJ, Gordon JI. Expression of rat intestinal fatty acid-binding protein in escherichia coli. Purification and comparison of ligand binding characteristics with that of escherichia coliderived rat liver fatty acid-binding protein. J. Biol. Chem. 1987;262(12):5931-5937. https://doi.org/10.1016/S00219258(18)45664-5

[69] Baier LJ, Bogardus C, Sacchettini JC. A Polymorphism in the human intestinal fatty acid binding protein alters fatty acid transport across Caco-2 cells. J Biol Chem. 1996;271(18):10892-10896. https://doi.org/10.1074/jbc.271.18.10892

[70] Albala C, Santos JL, Cifuentes M, et al. Intestinal FABP2 A54T polymorphism: Association with insulin resistance and obesity in women. Obes Res. 2004;12 (2):340-345. https://doi.org/10.1038/oby.2004.42

[71] Han TK. Effects Ala54Thr polymorphism of FABP2 on obesity index and biochemical variable in response to a aerobic exercise training. J Exerc Nutr Biochem. 2013;17(4):209-217. https://doi.org/10.5717/jenb.2013.17.4.209

[72] Zhao T, Nzekebaloudou M, lv J. Ala54Thr polymorphism of fatty acid-binding protein 2 gene and fasting blood lipids: A meta-analysis. Atherosclerosis. 2010;210(2):461-467. https://doi.org/10.1016/j.atherosclerosis.2009.11.049

[73] Fisher E, Li Y, Burwinkel B, et al. Preliminary evidence of FABP2 A54T polymorphism associated with reduced risk of type 2 diabetes and obesity in women from a German Cohort. Horm Metab Res. 2006;38(5):341-345. https://doi. org/10.1055/s-2006-925400

[74] Nasibulina ES, Borisova AV, Akhmetov II. Study on association of FABP2 gene Ala54Thr polymorphism with risk of obesity, body fat mass and physical activity. Vopr Pitan. 2013;82(5):23-28.

[75] Muoio DM, Leddy JJ, Horvath PJ, Awad AB, Pendergast DP. Effect of dietary fat on metabolic adjustments to maximal VO2 and endurance in runners. Med Sci Sport Exerc. 1994;26(1):81-88. https://doi.org/10.1249/00005768-199401000-00014

[76] Leońska-Duniec A, Świtała K, Ahmetov II, et al. FABP2 Ala54Thr polymorphism and post-training changes of body composition and biochemical parameters in Caucasian women. Genes. 2021;12:954. https://doi.org/10.3390/ genes12070954

[77] Fujie S, Iemitsu M, Murakami H, et al. Higher cardiorespiratory fitness attenuates arterial stiffening associated with the Ala54Thr polymorphism in FABP2. Physiol. Genomics 2013;45(6):237-242. https://doi.org/10.1152/ physiolgenomics.00089.2012

[78] Frayling TM, Timpson NJ, Weedon MN, et al. A common Variant in the FTO gene is associated with body mass index and predisposes to childhood and adult Obesity. Science. 2007;316(5826):889-894. https://doi.org/10.1126/ science.1141634

[79] Scuteri A, Sanna S, Chen WM, et al. Genome-Wide Association Scan shows genetic variants in the FTO gene are associated with obesity-related traits. PLoS Genet. 2007;3(7):e115. https://doi.org/10.1371/journal.pgen.0030115

[80] Dina C, Meyre D, Gallina S, et al. Variation in FTO contributes to childhood obesity and severe adult obesity. Nat. Genet. 2007;39(6):724-726. https://doi.org/10.1038/ng2048 
[81] Tung YCL, Yeo GSH, O’Rahilly S, Coll AP. Obesity and FTO: Changing focus at a complex locus. cell metabolism. Cell Press. 2014; November 4:710-718. https://doi.org/10.1016/j.cmet.2014.09.010

[82] Loos RJF, Yeo GSH. The bigger picture of FTO: the first GWAS-identified obesity gene. Nat Rev Endocrinol. 2014;10(1):51-61. https://doi.org/10.1038/nrendo.2013.227

[83] Leońska-Duniec A, Jastrzębski Z, Zarębska A, Maciejewska A, Ficek K, Cięszczyk P. Assessing effect of interaction between the FTO A/T polymorphism (rs9939609) and physical activity on obesity-related traits. J Sport Health Sci. 2018:7(4):459-464. https://doi.org/10.1016/j.jshs.2016.08.013

[84] Loos RJF. Genetic determinants of common obesity and their value in prediction. Best Pract Res Clin Endocrinol Metab. 2012:26(2):211-226. https://doi.org/10.1016/j.beem.2011.11.003

[85] Gerken T, Girard CA, Tung YCL, et al. The obesity-associated FTO gene encodes a 2-oxoglutarate-dependent nucleic acid demethylase. Science. 2007;318(5855):1469-1472. https://doi.org/10.1126/science.1151710

[86] Heffernan SM, Stebbings GK, Kilduff LP, et al. Fat mass and obesity associated (FTO) gene influences skeletal muscle phenotypes in non-resistance trained males and elite rugby playing position. BMC Genet. 2017;18(1):4. https://doi. org/10.1186/s12863-017-0470-1

[87] Guilherme JPLF, Egorova ES, Semenova EA, et al. The A-allele of the FTO gene rs9939609 polymorphism is associated with decreased proportion of slow oxidative muscle fibers and over-represented in heavier athletes. J Strength Cond Res. 2019;33(3):691-700. https://doi.org/10.1519/JSC.0000000000003032

[88] Zmijewski P, Leońska-Duniec A. Association between the FTO A/T polymorphism and elite athlete status in Caucasian swimmers. Genes. 2021;12(5):715. https://doi.org/10.3390/genes12050715

[89] Eynon N, Nasibulina ES, Banting LK, et al. The FTO A/T polymorphism and elite athletic performance: A study involving three groups of European athletes. PLoS One. 2013;8(4):1-6. https://doi.org/10.1371/journal.pone.0060570

[90] Kilpelainen TO, Qi L, Brage S, et al. Physical activity attenuates the influence of FTO variants on obesity risk A meta-analysis of 218,166 adults and 19,268 children. PLoS Med. 2011;8:e1001116. https://doi.org/10.1371/journal. pmed.1001116

[91] Li S, Zhao JH, Luan J, et al. Physical activity attenuates the genetic predisposition to obesity in 20,000 men and women from EPIC-Norfolk prospective population study. PLoS Med. 2010;31:7. https://doi.org/10.1371/journal.pmed.1000332

[92] Rampersaud E, Mitchell BD, Pollin TI, et al. Physical activity and the association of common FTO gene variants with body mass index and obesity. Arch Intern Med. 2008;168:1791-7. https://doi.org/10.1001/archinte.168.16.1791

[93] Vimaleswaran KS, Li S, Zhao JH, et al. Physical activity attenuates the body mass index-increasing influence of genetic variation in the FTO gene. Am J Clin Nutr 2009;90:425-8. https://doi.org/10.3945/ajcn.2009.27652

[94] Jonsson A, Renström F, Lyssenko V, et al. Assessing the effect of interaction between an FTO variant (rs9939609) and physical activity on obesity in 15,925 Swedish and 2511 Finnish adults. Diabetologia. 2009;52:1334-8. https:// doi.org/10.1007/s00125-009-1355-2

[95] Leońska-Duniec A, Ahmetov II, Zmijewski P. Genetic variants influencing effectiveness of exercise training programmes in obesity - an overview of human studies. Biol Sport. 2016;33(3): 207-214. https://doi.org/10.5604/20831862.1201052

[96] Cassard-Doulcier AM, Bouillaud F, Mattei MG, et al. Human uncoupling protein gene: structure, comparison with rat gene, and assignment to the long arm of chromosome 4. J Cell Biochem. 1990;43:255-264. https://doi.org/10.1002/ jcb.240430306

[97] Hoang T, Smith MD, Jelokhani-Niaraki M. Expression, folding, and proton transport activity of human uncoupling protein-1 (UCP1) in lipid membranes. J Biol Chem. 2013;288(51):36244-36258. https://doi.org/10.1074/jbc. M113.509935

[98] Nicholls DG, Locke RM. Thermogenic mechanisms in brow fat. Physiol Rev. 1984;64:61-64. https://doi.org/10.1152/ physrev.1984.64.1.1

[99] Ricquier D, Bouillaud F, Toumelin P, et al. Expression of uncoupling protein mRNA in thermogenic or weakly thermogenic brown adipose tissue. Evidence for a rapid beta-adrenoreceptor-mediated and transcriptional regulated step during activation of thermogenesis. J Biol Chem. 1986;261:13905-13910. https://doi.org/10.1016/S0021 9258(18)66957-1

[100] Bouillaud F, Villarroya F, Hentz E, Raimbault S, Cassard AM, Ricquier D. Detection of brown adipose tissue uncoupling protein mRNA in adult patients by a genomic probe. Clin Sci. 1988;71:291-297. https://doi.org/10.1042/ cs0750021

[101] Garruti G, Ricquier D. Analysis of uncoupling protein and its mRNA in adipose tissue deposits of adult humans. Int J Obes Relat Metab Disord. 1992;16(5):383-390

[102] Nagase I, Yoshida T, Kumamoto K, et al. Expressing of uncoupling protein in skeletal muscle and white fat of obese mice treated with thermogenic beta 3-adrenergic agonist. J Clin Invest. 1996;97:2898-2904. https://doi.org/10.1172/ JCI118748

[103] Nibbelink M, Moulin K, Arnaud E, Duval C, Pe'nicaud L, Casteilla L. Brown fat UCP1 is specifically expressed in uterine longitudinal smooth muscle cells. J Biol Chem. 2001;276:47291-47295. https://doi.org/10.1074/jbc. M105658200

[104] Bouillaud F, Villarroya F, Hentz E, Raimbault S, Cassard AM, Ricquier D. Detection of brown adipose tissue uncoupling protein mRNA in adult patients by a genomic probe. Clin Sci. 1988;75(1):21-27. https://doi.org/10.1042/cs0750021

[105] Garruti G, Ricquier D. Analysis of uncoupling protein and its mRNA in adipose tissue deposits of adult humans. Int J Obes Relat Metab Disord. 1992;16:383-390.

[106] Huttunen P, Kortelainen MJ. Long-term alcohol consumption and brown adipose tissue in man. Eur J Appl Physiol. 1990;60:418-424. https://doi.org/10.1007/BF00705030

[107] Lowell BB, Flier JS. Brown adipose tissue, -3-adrenergic receptors, and obesity. Ann Rev Med. 1997;48:307-316. https://doi.org/10.1146/annurev.med.48.1.307

[108] Oppert JM, Vohl MC, Chagnonl M, et al. DNA polymorphism in the uncoupling protein (UCP) gene and human body fat. Int J Obes 1994;18:526-531. 
[109] Heilbronn LK, Kind KL, Pancewicz E, Morris AM, Noakes M, Clifton PM. Association of -3826G variant in uncoupling protein-1 with increased BMI in overweight Australian women. Diabetologia. 2000;43:242-244. https://doi.org/10.1007/ s001250050036

[110] Oh HH, Kim KS, Choi SM, Yang HS, Yoon Y. The effects of uncoupling protein-1 genotype on lipoprotein cholesterol level in Korean obese subjects. Metabolism. 2004;53(8):1054-1059. https://doi.org/10.1016/j.metabol.2004.02.014

[111] Kieć-Wilk B, Wybranńska I, Malczewska-Malec M, et al. Correlation of the -3826 A? G polymorphism in the promoter of the uncoupling protein 1 gene with obesity and metabolic disorders in obese families from southern Poland. J Physiol Pharmacol. 2002;53:477-490.

[112] Kogure A, Yoshida T, Sakane N, Umekawa T, Takakura Y, Kondo M. Synergic effect of polymorphisms in uncoupling protein 1 and beta3-adrenergic receptor genes on weight loss in obese Japanese. Diabetologia. 1998;41:1399. https:// doi.org/10.1007/s001250051084

[113] Fumeron F, Durack-Bown I, Betoulle D, et al. Polymorphisms of uncoupling protein (UCP) and beta 3 adrenoreceptor genes in obese people submitted to a low calorie diet. Int J Obes Relat Metab Disord. 1996 Dec;20(12):1051-4.

[114] Ghachem A, Paquin J, Brochu M, Dionne IJ. Should waist circumference cutoffs in the context of cardiometabolic risk factor assessment be specific to sex, age, and BMI? Metab Syndr Relat Disord. 2018;16(7):366-374. https://doi. org/10.1089/met.2017.0177

[115] Hu FB. Physical activity, sedentary behaviours, and obesity. Obes Epidemiol. 2008;301-319. https://doi.org/10.1093/ acprof:oso/9780195312911.003.0015

[116] Healy GN, Dunstan DW, Salmon J, et al. Objectively measured light-intensity physical activity is independent associated with 2-h plasma glucose. Diabetes Care. 2007;30:1384-1389. https://doi.org/10.2337/dc07-0114

[117] Thorleifsson G, Walters GB, Gudbjartsson DF, et al. Genome-wide association yields new sequence variants at seven loci that associate with measures of obesity. Nat. Genet. 2009;41:18-24. https://doi.org/10.1038/ng.274

[118] Loos RJ. Genetic determinants of common obesity and their value in prediction. Best Pract Res Clin Endocrinol Metab. 2012;26(2):211-226. https://doi.org/10.1016/j.beem.2011.11.003

[119] Hinney A, Albayrak O, Antel J, et al. Genetic variation at the CELF1 (CUGBP, elav-like family member 1 gene) locus is genome-wide associated with Alzheimer's disease and obesity. Am J Med Genet Part B. 2014;165B:283-293. https://doi.org/10.1002/ajmg.b.32234

[120] Tan LJ, Zhu H, He H, et al. Replication of 6 obesity genes in a meta-analysis of genome-wide association studies from diverse ancestries. PLoS ONE 2014;9:e96149. https://doi.org/10.1371/journal.pone.0096149

[121] García-Solís P, Reyes-Bastidas M, Flores K, et al. Fat mass obesity-associated (FTO) (rs9939609) and melanocortin 4 receptor (MC4R) (rs17782313) SNP are positively associated with obesity and blood pressure in Mexican schoolaged children. Br. J. Nutr. 2016;10:1-7. https://doi.org/10.1017/S0007114516003779

[122] Ahmad S, Rukh G, Varga TV, et al. Gene $\times$ physical activity interactions in obesity: Combined analysis of 111,421 individuals of Europe Anancestry. PLoS Genet. 2013;9(7):e1003607. https://doi.org/10.1371/journal.pgen.1003607 